臨床

\title{
小児の粘液囊胞における炭酸ガスレーザーの応用
}

\author{
守矢佳世子加藤 純 二* \\ 東京医科歯科大学大学院医歯学総合研究科摂食機能保存学講座䠘蝕制御学分野 \\ (主任 : 田上順次教授) \\ * 東京医科歯科大学大学院同研究科口腔機能発育講座口腔機能育成学分野 \\ (主任 : 高木裕三教授)
}

(受理 : 平成 14 年 7 月 11 日)

\section{Application of a $\mathrm{CO}_{2}$ Laser for Removal of Oral Mucocle in Children}

\author{
Kayoko MORIYA and Junji KATO* \\ Cariology and Operative Dentistry, Department of Restorative Sciences, \\ Division of Oral Health Sciences, Graduate School, \\ Tokyo Medical and Dental University \\ (Chief : Prof. Junji TAGAMI) \\ * Development of Oral Health Science, Department of Orofacial \\ Development and Function, Division of Oral Health Sciences, \\ Graduate School, Tokyo Medical and Dental University \\ (Chief : Prof. Yuzo TAKAGI)
}

(Accepted for Publication: July 11, 2002)

\begin{abstract}
The objective of this study was to clarify the effect of $\mathrm{CO}_{2}$ laser irradiation on oral tissue problems in children, especially to treat mucocele. This study was carried out in the pedodontic clinic of Tokyo Medical and Dental Hospital for 7 years between 1995 and 2001. A $\mathrm{CO}_{2}$ laser was used on 29 subjects, of ages between 0 to 15 , having a mucocele on lip, lingual, or buccal mucosa. In each case, after administration of local anesthesia, the border of the mucocele was first incised around by a $\mathrm{CO}_{2}$ laser in 3 or 4 watt continuous mode. Thereafter, the mass of the mucocele was completely removed away from the adjoining normal tissue, without breaking its wall. No cases required suturing. The results were as follows: 1. A mucocele of lip or lingual mucosa, with a rich blood supply, was efficiently removed, without bleeding, giving a clear operative field during the operation; 2 . The surgery itself was simple and less time-consuming; 3 . After two or three weeks the wound was completely healed without almost any discomfort in all patients; 4 . Wound contraction and scarring were decreased or eliminated; 5 . Reoccurrence of a mucocele was not seen, except for one case of a lingual mucocele. In conclusion the use of a $\mathrm{CO}_{2}$ laser proved to be a very safe and effective mode for the removal of mucocele, especially in small children.
\end{abstract}

(J. Jpn. Soc. Laser Dent. $13: 97 \sim 103,2002$ Reprint requests to Dr. MORIYA)

Key words=laser, Mucocele, Children

キーワード＝炭酸ガスレーザー，粘液囊胞，小児

于113-8549 東京都文京区湯島 1-5-45 TEL 03-5803-5483 FAX 03-5803-0195 ${ }^{*}$ TEL 03-5803-5543 FAX 03-5803-0204

1-5-45 Yushima Bunkyo-ku, 113-8549, Tokyo, Japan. TEL 81-3-5803-5483 FAX 81-3-5803-0195

${ }^{*}$ TEL 81-3-5803-5543 FAX 81-3-5803-0204 


\section{緒言}

粘液囊胞は唾液の流出障害によって生じる襄胞である。 口腔軟組織に生じる囊胞では最も頻度が高いといわれ1,2), そのため日常臨床においても遭遇することの多い疾患であ る。比較的若年者に多く見られ, 就学前の幼児に見られる ことも稀ではない。とくに低年齢児では協力が得にくいこ となどから，外来での処置が敬遠されることも少なくない。

著者らは, 東京医科歯科大学歯学部附属病院小児歯科外 来において, 平成 7 年度より小児患者の粘液囊胞摘出に炭 酸ガスレーザーを応用したところ, 短時間かつ簡便な術式 で, 良好な術後経過が得られ, 協力の得られない乳幼児に おいても外来での処置が可能であることがわかった。平成 13 年度までに 29 症例を経験し, 良好な結果が得られたの で症例とともにこれを報告する。

\section{対象および使用機器}

平成 7 年度より平成 13 年度までの間に東京医科歯科大 学歯学部附属病院小児歯科外来を受診し, 粘液囊胞を認め た患児 29 名（男子 8 名，女子 21 名）に対し，レーザーに よる摘出術を行った。

使用したレーザーは波長 $10.6 \mu \mathrm{m}$ の炭酸ガスレーザー で，主としてパナラス $\mathrm{C} 05$ および $\mathrm{C} 10$ (松下産業機器社製) を使用した。このレーザーは，柔軟な光ファイバーによっ てレーザー光が導光されるため操作性に優れ，小児の口腔 内のような狭い照射野でも安全に使用することができた。 先端チップには直径 $0.6 \mathrm{~mm}$ の金属製テーパーチップを使 用した。機器の詳細を表 1 に示す。

\section{術式}

局所麻酔下に, 連続波, 出力 $3 \mathrm{~W}$ ないし $4 \mathrm{~W}$ の照射条件 で, 霊胞周囲に切開線を入れ, 跙胞壁を周囲組織から剥離 するようにして囊胞を一塊として摘出した。摘出後は開放 創とし, 縫合は行わなかった。レーザー使用時間は正味 5 分前後であり, 浸潤麻酔から処置終了までに要した時間も おおよそ15 分以内であった。

\section{結 果}

\section{1. 患児の年齢と発生部位}

患児の年齢分布を図 1 に示した。最も多かったのは小学 校低学年にあたる 7 歳 9 歳で全体の約 3 割を占め, 年齢 が上がるにつれ人数の減少が見られた。また, 就学前では, 3 歳以下の乳児が 4 歳以上を上回った。

粘液囊胞の発生部位は表 2 のとおりであった。すなわち 下唇が最も多く, 22 例 (75.9\%) で, ついで舌の 4 例 (13.8
表 1 Panalas C05 および C10

\begin{tabular}{|c|c|}
\hline レーザー種類 & 炭酸ガスレーザー \\
\hline 発振波長 & $10.6 \mu \mathrm{m}$ \\
\hline \multirow[t]{2}{*}{ 出力範囲 } & $1 \mathrm{~W} \sim 10 \mathrm{~W}(\mathrm{C} 10)$ \\
\hline & $1 \mathrm{~W} \sim 5 \mathrm{~W}(\mathrm{C} 05)$ \\
\hline 照射モード & 連続波, パルス波, SP 波 \\
\hline 伝送方式 & フレキシブル光ファイバー方式 \\
\hline 先端部 & 金属製チップ \\
\hline 照射部冷却機構 & アシストガス (空気) による冷却 \\
\hline
\end{tabular}

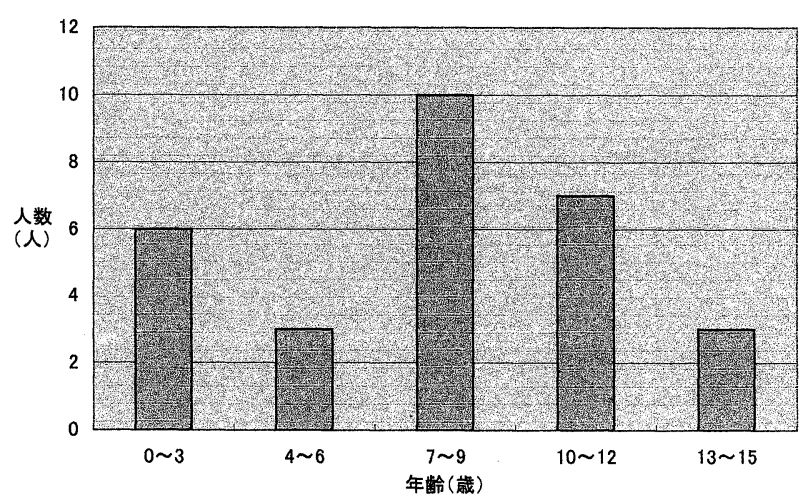

図 1 患児の年齢別人数

表 2 粘液囊胞の発生部位別人数

\begin{tabular}{cc}
\hline 発生部位 & 人数 $(\%)$ \\
\hline 上唇 & $1(3.4)$ \\
下唇 & $22(75.9)$ \\
舌 & $4(13.8)$ \\
煩粘膜 & $2(6.9)$ \\
\hline 計 & $29(100)$ \\
\hline
\end{tabular}

$\%)$, 㚘粘膜の 2 例（6.9\%）となった。上唇は下唇に比べ て少なく, 1 例 $(3.4 \%)$ のみであった。

\section{2 . 処置内容と臨床経過}

表 3 に全症例の処置内容拉よび臨床経過を示した。当初 は通常の外科的処置の場合に準じて鎮痛薬や抗菌薬の投与 を行ったが, 術直後より出血がなく創面の露出もないこと や，患児や保護者への問診より術後疼痛がほとんどないこ とから，使用しなくなった。疼痛を訴えた症例が 2 例あっ たが，いずれも処置当日のみで，摂食時の誘発痛であった。 術後の経過は囊胞の大きさや部位によって差が見られたも のの, 糞胞の摘出による患部の陥凹感は早期に消失した。 術後 1 週目では, 創面全体が偽膜に覆われている様子が観 察された。その後徐々に創部は縮小し, 術後 2 週目から 3 
2002年 9 月 守矢佳世子・他 小览の粘液囊胞における炭酸ガスレーザーの応用

表 3 処置内容および臨床経過

\begin{tabular}{|c|c|c|c|c|c|c|c|c|c|c|c|}
\hline 患者 & 年齢 & 性別 & 処置部位 & 使用条件 & 投薬 & 術後疼痛 & 1 週後 & 2 週後 & 3 週後 & 1 カ月 & 備考 \\
\hline Y.T & 12 & $\mathrm{~F}$ & 下唇 & $3 \mathrm{~W}$ & なし & - & $\triangle$ & $\triangle$ & 0 & (2) & \\
\hline Y.Y & 5 & M & 下唇 & $3 \mathrm{~W}$ & 鎮痛薬 & - & $\triangle$ & $\triangle$ & $\bigcirc$ & (2) & \\
\hline Y.M & 10 & $\mathrm{~F}$ & 下唇 & $3 \mathrm{~W}$ & 抗菌薬 & - & $\triangle$ & $\triangle$ & 0 & () & \\
\hline Y.T & 14 & $\mathrm{~F}$ & 下唇 & $3 \mathrm{~W}$ & なし & - & $\triangle$ & $\triangle$ & 0 & () & \\
\hline Y.M & 10 & $\mathrm{~F}$ & 下唇 & $3 \mathrm{~W}$ & なし & - & $\triangle$ & $\triangle$ & 0 & (2) & \\
\hline $\mathrm{K} . \mathrm{Y}$ & 8 & $\mathrm{~F}$ & 下唇 & $3 \mathrm{~W}$ & なし & - & $\triangle$ & $\triangle$ & 0 & (2) & \\
\hline H.K & 1 & M & 下唇 & $3 \mathrm{~W}$ & 抗菌薬 & - & $\triangle$ & $\triangle / O$ & 0 & () & \\
\hline S.Y & 3 & $\mathrm{~F}$ & 下唇 & $3 \mathrm{~W}$ & 抗菌薬 & - & $\triangle / \bigcirc$ & 0 & (2) & () & \\
\hline K.A & 10 & $\mathrm{~F}$ & 下唇 & $3 \mathrm{~W}$ & なし & - & $\triangle$ & $\triangle / O$ & 0 & (2) & \\
\hline I.E & 7 & M & 下唇 & $3 \mathrm{~W}$ & なし & - & $\triangle$ & $\triangle / \bigcirc$ & 0 & (C) & \\
\hline N. I & 14 & $\mathrm{~F}$ & 舌 & $3 \mathrm{~W}$ & なし & - & $\triangle$ & $\triangle$ & $\triangle / \bigcirc$ & () & 再発 \\
\hline Y.M & 10 & $\mathrm{~F}$ & 下唇 & $3 \mathrm{~W}$ & なし & - & $\triangle$ & $\triangle / O$ & 0 & (0) & \\
\hline Y.Y & 1 & M & 下唇 & $3 \mathrm{~W}$ & なし & - & $\triangle$ & $\triangle / O$ & 0 & (C) & \\
\hline K.Y & 15 & $\mathrm{~F}$ & 下唇 & $3 \mathrm{~W}$ & なし & - & $\triangle$ & $\triangle / O$ & 0 & (2) & \\
\hline O.A & 6 & $\mathrm{~F}$ & 頼 & $3 \mathrm{~W}$ & なし & - & $\triangle$ & $\triangle / O$ & 0 & (0) & \\
\hline $\mathrm{T} . \mathrm{H}$ & 7 & $\mathrm{~F}$ & 下唇 & $3 \mathrm{~W}$ & なし & - & $\triangle$ & $\triangle / O$ & 0 & (2) & \\
\hline T.H & 7 & $\mathrm{~F}$ & 下唇 & $3 \mathrm{~W}$ & なし & - & $\triangle$ & $\Delta / O$ & 0 & (a) & \\
\hline M. S & 9 & $\mathrm{~F}$ & 下唇 & $3 \mathrm{~W}$ & なし & - & $\triangle$ & 0 & (2) & (2) & \\
\hline I. T & 9 & $\mathrm{M}$ & 舌 & $3 \mathrm{~W}$ & なし & 軽微 & $\triangle$ & $\triangle$ & 0 & (2) & \\
\hline F.M & 4 & $\mathrm{~F}$ & 下唇 & $3 \mathrm{~W}$ & なし & - & $\triangle$ & $\triangle$ & 0 & (a) & \\
\hline K.A & 3 & $\mathrm{~F}$ & 下唇 & $3 \mathrm{~W}$ & なし & 誘発痛 & $\triangle$ & 0 & (a) & (a) & \\
\hline M. K & 11 & F & 下唇 & $3 \mathrm{~W}$ & なし & - & $\triangle$ & $\triangle$ & 0 & (0) & \\
\hline N.Y & 1 & $\mathrm{~F}$ & 下唇 & $3 \sim 4 \mathrm{~W}$ & なし & - & $\triangle$ & $\Delta / \bigcirc$ & 0 & (2) & \\
\hline Y.T & 0 & $\mathrm{M}$ & 歯肉煩 & $4 \mathrm{~W}$ & なし & - & $\triangle$ & $\Delta / O$ & 0 & () & \\
\hline S.R & 8 & $\mathrm{~F}$ & 上唇 & $4 \mathrm{~W}$ & なし & - & $\triangle$ & $\Delta / O$ & 0 & (a) & \\
\hline Y.Y & 10 & F & 下唇 & $3 \sim 4 \mathrm{~W}$ & なし & - & $\triangle$ & $\triangle / O$ & 0 & (2) & \\
\hline F.M & 7 & $\mathrm{~F}$ & 下唇 & $3 \sim 4 \mathrm{~W}$ & なし & - & $\triangle$ & 0 & (a) & (a) & \\
\hline $\mathrm{K} . \mathrm{H}$ & 9 & $\mathrm{M}$ & 舌 & $4 \mathrm{~W}$ & なし & - & $\triangle$ & $\triangle$ & 0 & (2) & \\
\hline N.H & 9 & $\mathrm{M}$ & 舌 & $4 \mathrm{~W}$ & なし & - & $\triangle$ & 0 & 0 & () & \\
\hline
\end{tabular}

週目で, 新生粘膜で覆われ治癒に至った。術後 1 力月で瘀 痕もほとんど消失した。

再発は全 29 症例中，舌尖部粘液囊胞に 1 症例（3.4\%） みられた。

以下，臨床例を示す。

\section{症例 1 下唇粘液囊胞症例}

患児は生後 8 力月の男児である。歯肉煩移行部近くの粘 膜に境界明瞭な嚢胞がみとめられた（図 2)。局所麻酔の のち, 連続波, 出力 $4 \mathrm{~W}$ の照射条件下に, チップの先端を わずかに浮かせて組織に接触させないよう注意しながら， 照射した。まず，襄胞辺縁に沿って，全周にわたって深さ $1 \mathrm{~mm}$ 程度の切開を加えた。その後, ピンセットで囊胞上 部をつまみあげ，頸部周囲にややディフォーカスになるよ
うに照射していった（図3）。照射するにつれ，次第に囊 胞の全貌が現われ，最終的に一塊として除去することが可 能であった（図 4)。粪胞除去後，創面を観察して粟粒様 の小酷液腺がみられる場合は，ピンセットでつまみながら 同じ要領で除去した。凸凹感が消え平坦な創面となったと ころで, 創面をディフォーカスでまんべんなく照射し，表 面に一層の被膜を作るようにした。図 5 は術直後の創面の 様子であるが, 出血はほとんどみられなかった。開放創の まま終了し，投薬は行わなかった。10日後，陥凹は消失 し，一部白色の偽膜が残るものの創面は縮小しており，周 囲から粘膜の新生が認められた（図 6)。炎症, 感染など の不快事項はみられなかった。なお，患児は低年齢である ことから安全のためレストレーナーによる抑制下で処置を 


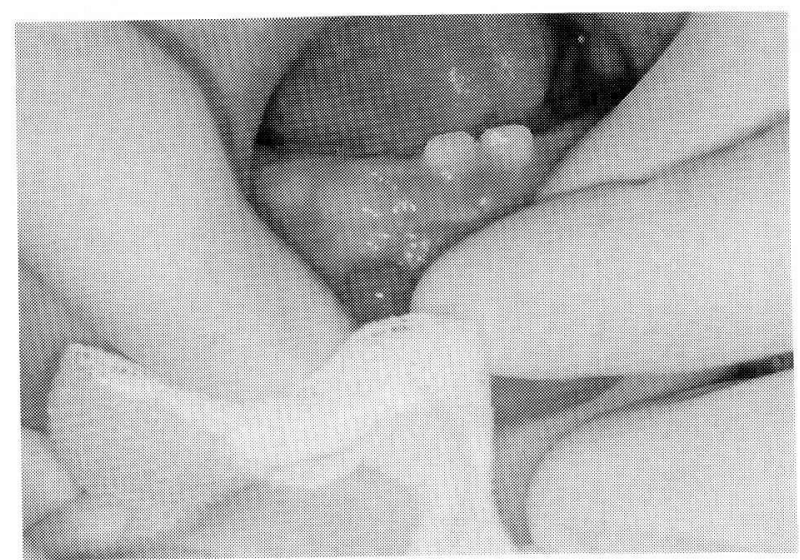

図 28 力月男児。小豆大の囊胞が認められる。

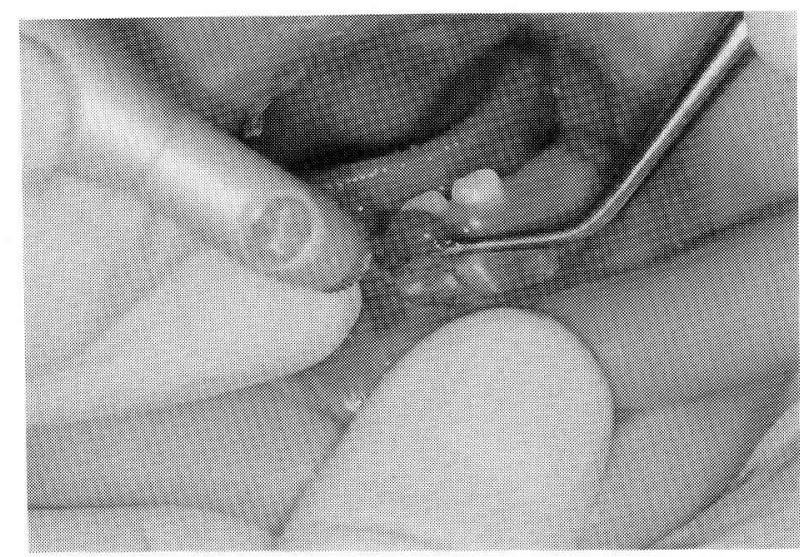

図 3 ピンセットで囊胞上部を持ち上げ，ややディフォーカ スで頸部にレーザー照射する。

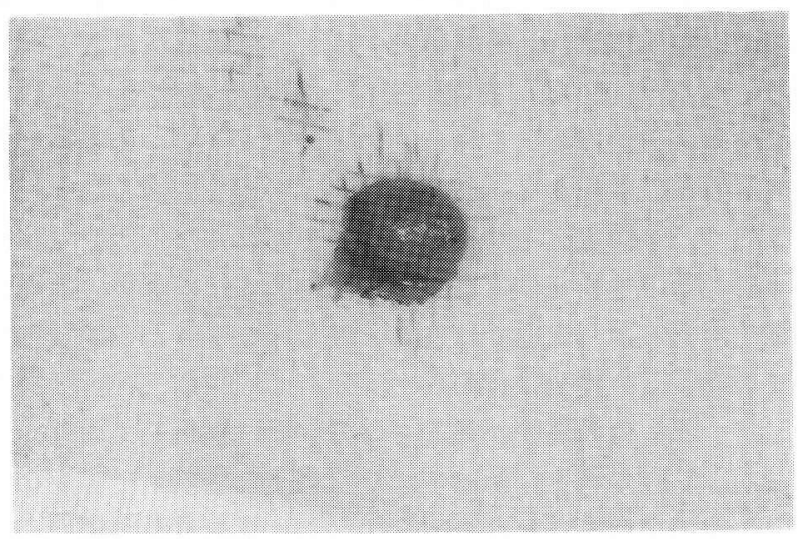

図 4 摘出した粘液哑胞, 直径 $5 \mathrm{~mm}$ 。

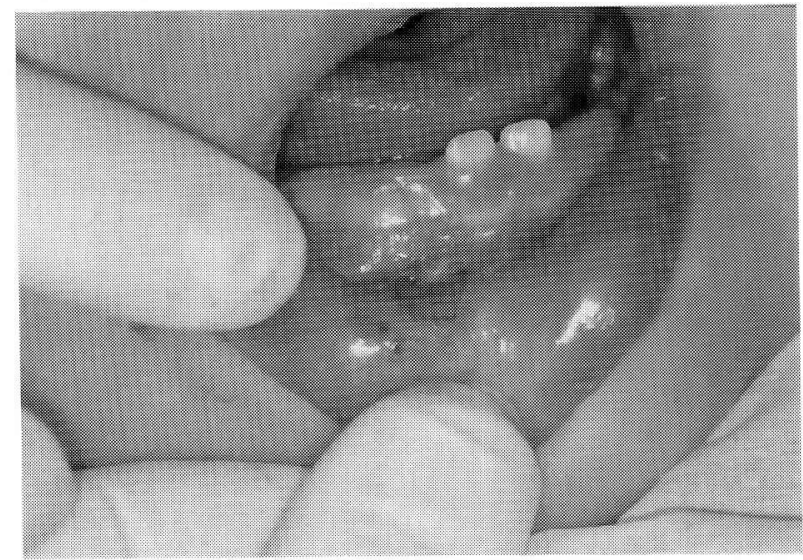

図 5 術直後の創面。出血はほとんど見られない。縫合はし なかった。

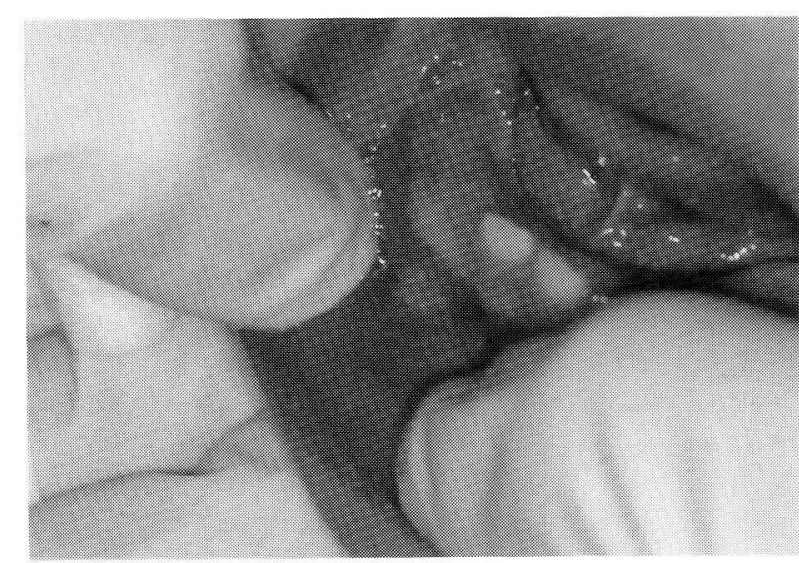

図 610 日後。創面の縮小と, 粘膜の新生が認められる。

行ったが，誤照射等の問題もなく処置は 15 分で終了した。

\section{症例 2 舌粘液囊胞症例}

患児は 9 歳の男児である。舌下面に粘液囊胞を認めた (図 7)。囊胞周囲に局所麻酔を行い, 連続波, 出力 $3 W$ で, 下唇粘液囊胞症例と同様に襄胞ごと周囲組織から剥離する 要領で摘出を行った。舌は可動範囲が大きく, 自力で静止 させることは困難であったが, 図8のように口腔内バキュー ムで吸引し，拣引することで固定が可能になった。震胞摘 出直後は創部の隙凹が顕著であったが，他の部位の粘液囊 胞症例と同様に出血は見られなかった。縫合は行わず, 開 放創として処置を終了した（図 9）。処置当日，やや食物 による誘発痛があったほかは，術後の疼痛はなかった。炎 症，感染なども見られず約 3 週間で治癒に至った。 


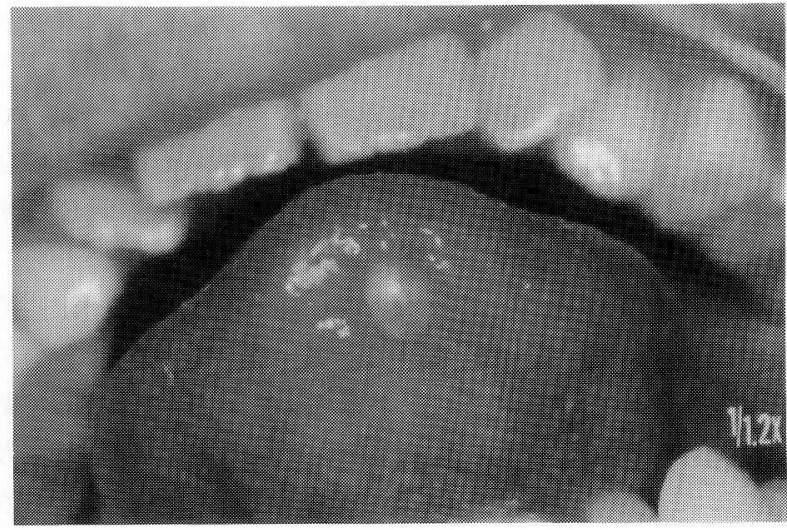

図 79 歳男览。舌尖部下面に粘液囊胞が認められる。

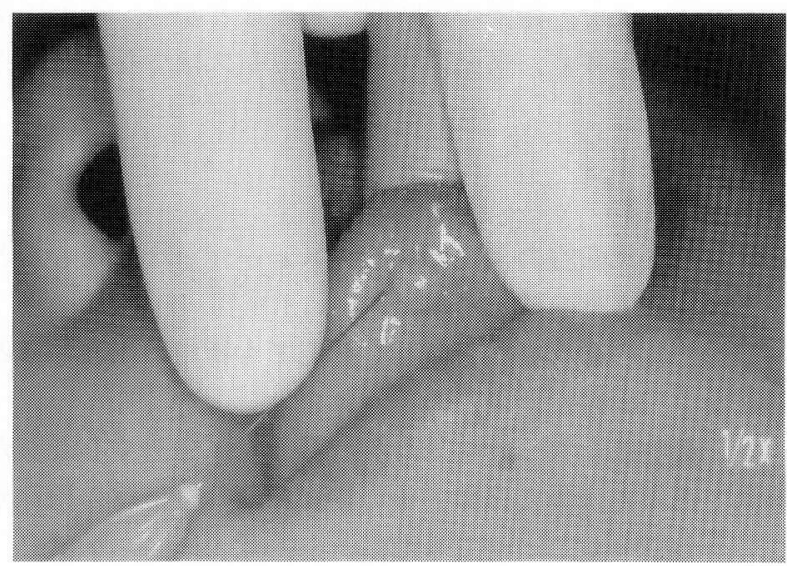

図 8 舌の固定には口腔内バキュームを使用した。

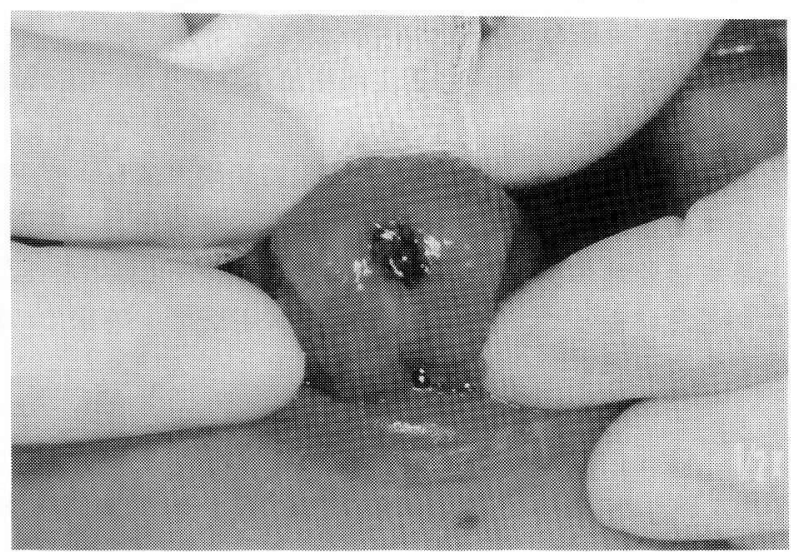

図 9 術直後。出血は認められず，開放創とした。

\section{考察}

1. 粘液囊胞について

粘液囊胞は下唇，㚘粘膜，口腔底，舌などにみられ，ま
れに口蓋や臼後部などでの発症も報告されている ${ }^{3)}$ 。口腔 底に生じた囊胞は別名ガマ腫, 舌下面に生じた囊胞につい ては Blandin-Nuhn 震胞とも呼ばれている。粘液囊胞の成 因については唾液の流出障害によって生じるとの考え方が 一般的で，唾液腺あるいは導管が破綻することにより周囲 組織へ棰液が漏洩して発生することが，荒記によって実験 的に証明されている4)。臨床的には咬傷や，歯列矯正具， 䠛蝕歯，歯列不正などに起因する粘膜への反復する慢性刺 激，あるいは歯牙の交換，萌出の関与などが疑われている。 粘液囊胞に対する臨床統計学的調査によれば1-3,5-9)，患者は やや女性に多いとする報告が多い。今回対象とした 29 名 の患児においても，女児が 21 名を占めており，女児に多 い傾向が認められた。また，粘液囊胞は若年層に患者が多 く, 20 歳未満の患者の比率が 4 割から 6 割の間を占める

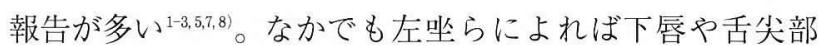
下面にみられる粘液囊胞は 10 歳未満に多く，下唇粘液囊 胞症例で 1 歳 $３$ 歳拉よび 6 歳 $８$ 歳にピークが見られた と報告している5)。粘液囊胞の誘因として, Kroll らは歯 の萌出，交換に伴う歯牙接触を挙げており ${ }^{10)}$ ，また熊谷ら は乳前歯の脱落と永久歯の萌出に伴って, 下唇に抢ける粘 液囊胞の発生部位が, 正中部から犬歯部へ変化していくこ とを報告している9”。今回の報告に打いても対象患児のう

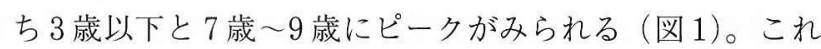
は乳歯や永久前歯の萌出時期と重なり, これまでの報告と 同様，歯牙の萌出期と粘液囊胞の発生との関連を示唆する と考えられた。

\section{2. 治療法について}

粘液囊胞の治療法は，全摘出術のほか，開空術，凍結療 法 ${ }^{11,12)}$ ，ステロイドによる薬物療法5)，口腔習癖の除去を目 的とした床装置による治療法 ${ }^{13}$, 縫合系による結禁療法 ${ }^{14}$ などが，これまでに報告されている。一般的には，囊胞の 全摘出を行うことが多く, 開空術や凍結療法に比べ予後も 良好であるといわ扎ている 2.5 .7$) 。$ 摘出の際に取り残しがあ ると再発しやすいため，囊胞壁を破壞しないようにするだ けでなく, 関連する病的な導管や崜液腺も全て除去するこ とが重要といわれる。また，手術操作による隣接腺管の侵 襲も再発の原因となり得るため，これを可及的に少なくす ることが望ましいと考えられる ${ }^{1,2)}$

著者らが行ってきた炭酸ガスレーザーを用いた術式では， 囊胞を蒸散するのではなく, 初めにレーザーメスとして囊 胞周囲の切開に用い, 囊胞上部と周囲組織との間に切り込 みを入れたあと, 続いて囊胞壁を周囲組織から鈍的に剥離 する目的でディフォーカス光を照射した。その結果，囊胞 の剥離は容易であり，図 4 に示したとおり囊胞壁を壊さず 一塊として囊胞を摘出することが可能であった。このよう 
なことから, 囊胞上部の粘膜ごと除去する点や摘出後に縫 合しない点を除けば，本方法はほぼ従来の外科的な摘出術 に準ずる様式と考えられる。外科的摘出の際にも囊胞上部 の粘膜の一部を付着させたまま摘出するという報告もあり， そのことで譲胞の牽引，剥離が容易にできるとしている。 実際，今回のレーザーによる摘出においても，囊胞上部の 粘膜ごと摘出することで囊胞が破れにくくなると考えられ た。また，摘出後縫合をせず，開放創のままで良好な治瘉 経過が得られたことにより，処置が簡便になり，処置時間 が短縮された。加えて術中の出血がほとんどないため，口 唇など血管豊富な組織においても術野は常に明瞭で, 震胞 除去後の創面に対しての関連腺管の取り残しの有無の確認 や，その除去が可能であった。

また炭酸ガスレーザー光は， $10.6 \mu \mathrm{m}$ という波長が水の 吸収スペクトルのピークにほぼ一致するために水分によく 吸収される事が知られている。このため生体軟組織を対象 とした場合にエネルギーの大部分が照射部表層で吸収され るという特徵がある。したがって，周囲組織に対する熱為 害作用は少ないといわれ ${ }^{16)}$, このことが術後疼痛の少なさ や，囊胞除去後の陥凹の早期回復，また瘷痕が残りにくい ことと関連していると思われる。以前に著者らが報告した, 炭酸ガスレーザーを応用した小帯切除症例の場合も, 術後 痛や瘏痕について同様の結果が得られており ${ }^{17)}$ ，これらの ことは炭酸ガスレーザーを口腔軟組織に応用した際の特徴 と考えられた。

\section{3. 再発について}

粘液囊胞は比較的再発しやすい疾患といわれ, 全摘出術 を行った症例でも $10 \%$ 前後に再発が見られたとする報告 が多い2,3,5,7,9)。これについては関連唾液腺の取り残しや, 手術操作によって新たに周囲の唾液腺を傷害してしまうこ となどが原因と考元られている。今回対象とした 29 症例 では, 予後観察期間は最低 6 力月以上, 最高 6 年 6 力月で あったが, 再発を認めた症例は, 舌尖部に発生した粘液囊 胞1症例 $(3.4 \%)$ であった。この症例では, 震胞摘出の際 に囊胞壁を損傷したために囊胞を一塊として除去できず, やむなく周囲組織の蒸散を行った症例である。蒸散で肉眼 的には平坦な創面が得られたものの, 囊胞壁を取り残した ことにより, 再発したものと考えられる。それ以外の症例 についてはすべて術式で示した通り囊胞の全摘出を行って おり，この手法による再発は現在まで 1 例も観察されてい ない。したがって，炭酸ガスレーザーを用いた全摘出術に ついては，再発はほとんどないと考えられる。

4. 小児患者へのレーザー応用について

小児患者へのレーザーの使用に関しては, 既報の小帯切 除症例の場合 ${ }^{17)}$ と同様, 処置時間が短く, 出血や痛みなど
術中・術後の不快事項がほとんどないため, 高い協力性が 得られた。

その中で, 今回報告した 29 症例のうち 6 症例について は患児が 3 歳以下のいわゆる低年齢児であった。この時期 の子供では, 治療そのものや痛みを連想させる器具に対す る不安よりも, 特に母子分離から来る不安が大きいため, そのことによる号泣は避けられない。また治療開始時に協 力的な患児であっても術者の指示に対する集中力は極めて 低く，患児の不測の行動は免れない。したがってこの年齢 の患児については術前の協力度に関わらず，バスタオル及 びレストレーナーによる抑制のもとで処置を行った。しか しながら䠛蝕治療時におけるタービンなどの騒音やエアー, バキュームによる刺激に比べて，レーザー装置自体の刺激 要因は低いこと, 処置が短時間であることから, 術中に落 ち着く場合も多く，患児に対するストレスは少ないと考え られた。

\section{結 論}

小児の粘液囊胞の摘出に炭酸ガスレーザーを応用したと ころ, 次のような結果を得た。

1. 口唇のような血管豊富な部位でも術中の出血がほと んどなく，術野が明瞭にたもたれた。

2. 囊胞壁を傷つけにくく，一塊として除去することが 容易であった。また，除去後の創面に関連唾液腺の残存が ないか確認することができた。

3. 縫合を必要としないため, 処置が単純化された。

4. 術後の疼痛が少なく治癒の経過は良好であり, 創面 の㓔痕化がほとんどみられなかった。

5. 再発は 29 症例中, 舌尖部粘液囊胞の 1 例 $(3.4 \%)$ のみであった。

以上のことから，粘液囊胞の摘出に炭酸ガスレーザーを 応用することによって, 術式が短時間・簡便化し, 患者に とっては侵襲が少なく術後経過もよい治療が可能となった。 このことによって，とくに低年齢児において，外来での粘 液囊胞摘出が可能になった。

\section{謝 辞}

稿を終えるに当たり，この研究にご協力頂きました東京医科歯 科大学大学院口腔機能育成学分野医局員各位に深く感謝の意を表 します。

\section{文献}

1）石田 恵：口腔粘液蘘胞の臨床的ならびに組織学的研究. 病誌, $47: 447-464,1980$.

2）黑豆照雄：口腔粘液囊胞の臨床病理学的研究. 日口外誌, 29 : 393-403, 1982.

3）重松久夫, 江田 哲, 斉藤一彦, 渡辺 潔, 南弘子, 佐々 
木隆子, 大須賀 敏, 鈴木正二, 藤田訓也 : 粘液囊胞の臨床 病理学的検討. 日口科誌, $45: 258-262,1996$.

4）荒記春雅 : 口腔粘液囊胞の形成に関する実験的研究. 日口外 誌, $33: 467-484,1987$.

5) 左坐春喜, 篠原正徳, 友寄喜樹, 田代英雄, 岡 増一郎 : 唾 液腺粘液囊胞の臨床統計的検索。日口外誌, $28: 1545-1550$, 1982.

6）小澤孝紀，水野明夫，中村寿秀，川端泰三，茂野 徹，神谷 浩, 柴田隆夫, 鈴木章司, 式守道夫, 茂木克俊 : 小児唾液腺 停滞囊胞の検討. 日口科誌, $36: 138-144,1987$.

7) 藤本和久, 山田博基, 玉城廣保：当科における最近 11 年間 の唾液腺粘液囊胞に関する臨床統計的検討．日口外誌， 36 : 2258-2265, 1990

8）都留昭二, 杉本忠雄, 中村貴司, 岡田正明, 陸 方, 前川俊 之, 三浦正明, 真辺健一, 詫磨智恵, 黒川英雄, 梶山 稔 : 小児における粘液囊胞の臨床統計的観察．九州歯誌， 46 : 409-416, 1992.

9）熊谷和美, 富沢美恵子, 野田 忠, 鈴木 誠 : 小児の粘液囊 胞 55 例についての臨床病理学的観察. 小児歯誌, $33: 633-$ 642, 1995.

10) Krolls, S.O., Trodal, J. N. and Boyers, R.C.: Salivary Gland Lesion in Children. A survey of 430 cases. Cancer, $30:$ 459-469, 1972.
11）平出文久, 井上鉄三, 澤田政道, 椿 康喜代, 都川紀正, 田 中英一 : 凍結手術による下口唇および舌尖粘液囊胞の治療経 験. 耳喉, 54:65-69, 1982.

12）千葉 清, 藤森俊介, 小口順正, 山口一成, 工藤啓吾, 藤岡 幸雄 : 粘液囊胞に対する凍結手術。日口外誌, $24: 643-646$, 1978.

13）中村美保, 桑原未代子, 杉山知子, 根来道恵: 小児粘液囊胞 治療に㧍ける床装置の効果について．小览歯誌， $34: 1259$ 1266, 1996

14) Delbem, A.C.B., Cunba, R.F., Vieira, A.E.M. and Ribeiro, L.L.G.: Treatment of mucous retention phenomena in children by the micromarsupialization technique:case reports. Pediatr Dent, 22 : 155-158, 2000.

15）梶山 稔, 銅城将紘, 寺坂修治: 小唾液腺疾患および唾石症 の治療.歯界展望, 53:653-659, 1979.

16）加藤純二, 篠木毅, 守矢佳世子 : 各種レーザーの特徵と用途 を整理する (1)一波長特性と臨床効果の比較検討一。歯界展 望, $96: 33-48,2000$.

17）加藤純二, 守矢佳世子, 橋本吉明, 高木裕三 : 炭酸ガスレー ザーを応用した小児の口腔外科処置一小带切除術への応用一. 小児歯誌， $38 ： 897-905 ， 2000$ 。 